Artykuly / Articles

Lana Dalinczuk

ORCID: 0000-0001-9996-6865

lana.dalinczuk@op.pl

Siedlce University of Natural Sciences and Humanities

Faculty of Social Sciences

\title{
Organized crime as a threat to national security
}

\author{
Przestępczość zorganizowana jako zagrożenie \\ dla bezpieczeństwa narodowego
}

DOI: 10.34739/doc.2020.17.01

\begin{abstract}
All kinds of illegal trafficking, prostitution, pornography, gambling, fraud and counterfeiting, computer crime, corruption, piracy, illegal immigration and many other criminal activities can pose a threat to national and even international security if conducted by larger criminal groups or organizations. The phenomenon of organized crime has acquired a transnational character due to the increasing globalization of financial markets and communications as well as technological development. The three countries of East Central Europe - The Czech Republic, Hungary and Poland - can be of interest in terms of organized crime as recent political and economic developments in these countries have made them attractive to such criminal activities. Another problematic region in terms of organized criminal activities is the region of Central Asia which includes several countries of the former Soviet Union - Kazakhstan, Kyrgyzstan, Tajikistan, Turkmenistan and Uzbekistan.
\end{abstract}

Keywords: organized crime, national security, East Central Europe, Central Asia

Abstrakt: Wszelkiego rodzaju nielegalny handel, prostytucja, pornografia, hazard, oszustwa i fałszerstwa, przestępstwa komputerowe, korupcja, piractwo, nielegalna imigracja i wiele innych działań przestępczych moga stanowić zagrożenie dla bezpieczeństwa narodowego, a nawet międzynarodowego, jeśli sa popełniane przez większe grupy lub organizacje przestępcze. Zjawisko przestępczości zorganizowanej nabrało charakteru ponadnarodowego w wyniku postępującej globalizacji rynków finansowych i komunikacji oraz rozwoju technologicznego. Trzy kraje Europy Środkowo-Wschodniej - Czechy, Węgry i Polska - moga być interesujące pod względem funkcjonowania przestępczości zorganizowanej, ponieważ niedawne wydarzenia polityczne i gospodarcze w tych 
krajach sprawiły, że stały się one atrakcyjne dla takiej działalności przestępczej. Kolejnym problematycznym obszarem $z$ punktu widzenia przestępczości zorganizowanej jest region Azji Środkowej, który obejmuje kilka krajów byłego Zwiazku Radzieckiego - Kazachstan, Kirgistan, Tadżykistan, Turkmenistan i Uzbekistan.

Słowa kluczowe: przestępczość zorganizowana, bezpieczeństwo narodowe, Europa Środkowo-Wschodnia, Azja Środkowa

\section{Introduction}

Crime has always represented a threat to the security of people and often even to state organizations in all countries of the world. In recent years, however, the degree of this threat and its nature have changed in the way that it poses a greater problem for states and their citizens and in some cases even undermines the capability of governments to protect both the citizens and themselves ${ }^{1}$. All kinds of illegal trafficking (narcotics, arms, humans), prostitution, pornography, gambling, fraud and counterfeiting, computer crime, corruption, piracy, illegal immigration and many other criminal activities can pose a threat to national and even international security if conducted by larger criminal groups or organizations, thus becoming the so-called organized crime. In weaker states such activities can cause domestic economic or political instability, or even lead, in extreme cases, to state failure or collapse ${ }^{2}$. Colombia can serve here as a vivid example of such a situation where crime poses serious security threats. Criminal organizations in this country provide "a major human security threat" to both ordinary Colombians and foreign citizens and "have seriously undermined the capacity of the government to rule the country" 3 .

The term "organized crime" is often used to describe "a group of people who act together on a long-term basis to commit crimes for gain" 4 . A more precise definition of the term can be found in Article 2 of the UN Convention Against Transnational Organized Crime

${ }^{1}$ P. Hough, Understanding global security, London 2004, p. 216.

2 M.E. Smith, International security: politics, policy, prospect, Basingstoke 2010, p. $180-181$.

${ }^{3}$ P. Hough, Understanding global security...

${ }^{4}$ M. Levi, Perspectives on "organised crime”: an overview, „Howard Journal of Criminal Justice” 1998, 37(4), p. 335. 
signed in 2000 where organized crime is defined as "a structured group of three or more persons, existing for a period of time and acting in concert with the aim of committing one or more serious crimes or offences (...) in order to obtain, directly or indirectly, a financial or other material benefit"5. According to Giraldo \& Trinkunas, organized crime differs from other types of criminal activity by its structure as well as "through its reliance on corruption and systematic violence to attain high profit levels which are often laundered through reinvestment in the legal economy"6. These profit-driven crimes can be divided into three groups: predatory offences committed for profit which involve involuntary transfers, e.g. fraud; marketbased offences which involve production or distribution of illegal goods or services for profit, e.g. drug trafficking; and commercial offences which involve illegal production or distribution of legal goods or services, e.g. smuggling of cigarettes ${ }^{7}$. As it has already been mentioned above, such activities are seen as posing a serious harm to the society and the economy of a state.

\section{The phenomenon of organized crime}

First, it is necessary to look at the problem of organized crime in general as to what criminal activities are usually identified as major threats and when organized crime can pose a threat to national security. M.E. Smith argues that not all crimes should be given the status of security threats and that in order to identify specific criminal activities that pose a major threat one should measure their "destructive scale" 8 . According to the author, such criminal activities as money laundering, corruption and trade in narcotics represent the greatest revenues as compared to other crimes and amount to about 5-10 per cent of global $\mathrm{GDP}^{9}$. The recent data show that the

\footnotetext{
5 United Nations Office on Drugs and Crime, United Nations Convention against Transnational Organized Crime and the Protocols thereto, New York 2004, http://www.unodc.org/documents/treaties/UNTOC/Publications/TOC\%20Convention/TOCebook-e.pdf, (date of access: 29.11.2020).

6 J. Giraldo, H. Trinkunas, Transnational crime, [in:] Contemporary security studies, ed. A. Collins, Oxford 2007, p. 353.

7 R.T. Naylor, Towards a general theory of profit-driven crimes, „British Journal of Criminology" 2003, 43, p. 81-101.

8 M.E. Smith, International security...

9 Ibidem.
} 
estimated annual revenues from these crimes are as follows: money laundering - $\$ 590$ billion to $\$ 2$ trillion, corruption $-\$ 500$ billion to $\$ 1$ trillion, narcotics $-\$ 500$ billion to $\$ 1$ trillion $^{10}$. Other crimes which attract a great deal of attention as major threats are auto theft (\$9 billion), human trafficking ( $\$ 7$ billion), illicit arms smuggling (\$1 billion) $)^{11}$.

Apart from the economic costs, organized crime can also pose other threats to national as well as international security. Drug trafficking, for instance, can contribute to the levels of drug abuse, petty crime, and the spread of some diseases like HIV and AIDS ${ }^{12}$. Human trafficking for prostitution, illegal labour, illegal immigration and sale of children "adds a human rights/security dimension to the threat"13. One of the biggest human trafficking networks was broken in the UK in 2009. The network smuggled Afghans into Europe during the years 2005-08 and earned around $£ 200,000-300,000{ }^{14}$. As Giraldo \& Trinkunas observe, the human trafficking for prostitution does not only violate the civil and human rights of women, but can also endanger their health and welfare as well as threaten their families, home and host communities ${ }^{15}$.

It is also worth mentioning another kind of crime, the socalled cyber-crime, which is associated with the Internet and computer networks and which has become a real menace in recent years. The amount of attacks with computer viruses, identity theft and financial fraud by means of phishing email scams and false websites, and hacking into computer systems has significantly increased over the last decade. For instance, breaking into computer systems is regarded as a very serious threat as it enables criminals to steal important secret information and use it for illegitimate purposes. Since 2003 such organizations as the US National Aeronautics and Space Administration (NASA), the US Department of Defense, the US Congress, the UK Houses of Parliament as well as private companies, e.g. Lockheed Martin, have been targets of computer hacking and

\footnotetext{
10 Ibidem, p. 180.

11 Ibidem, p. 181.

12 J. Giraldo, H. Trinkunas, Transnational crime...

13 M.E. Smith, International security..., p. 181.

14 Ibidem.

15 J. Giraldo, H. Trinkunas, Transnational crime...
} 
have suffered theft of critical secret information ${ }^{16}$. In 2009 Lockheed Martin, an American aerospace, defense, security, and advanced technology company, was hacked by a Chinese spy network which stole the company's plans for the Joint Strike Fighter aircraft ${ }^{17}$.

Some scholars argue that organized crime becomes a national security threat when the level of harm caused by it "reaches epidemic proportions"18. What is more, most often criminals are seen as threats to national security rather than the criminal activities themselves as these people become rich and powerful thanks to corruption, violence and reinvestment of their profits in legal activities and may undermine the state and its economy. In extreme cases, criminal enterprises may challenge the ability of the state to fulfil its main functions as "guarantor of national sovereignty, the holder of the monopoly on force, and provider of the common good", as it took place in some of the drug-producing regions of Bolivia, Colombia and Peru ${ }^{19}$.

Organized crime can also undermine democratic stability. For instance, in new democracies many criminal enterprises took advantage of the instability during transitions and used corruption to influence the state agencies. According to Giraldo \& Trinkunas, the corruption of public institutions in new democracies can undermine public trust in the new regime and, in extreme cases, can even lead to its replacement, as it happened in Ukraine in 2004 during the Orange Revolution ${ }^{20}$. And finally, organized crime can pose a threat to economic development because it can undermine the rule of law and discourage foreign investments. Also, as mentioned above, criminals often reinvest their illicit profits in the licit economy, and such businesses often have "an unfair competitive advantage through their access to cheap capital and their ability to intimidate commercial adversaries"21.

When discussing organized crime one cannot omit the fact that this phenomenon has acquired a transnational character,

\footnotetext{
16 M.E. Smith, International security...

17 Ibidem.

18 J. Giraldo, H. Trinkunas, Transnational crime...

19 Ibidem, p. 348.

20 Ibidem.

21 Ibidem, p. 350.
} 
especially in recent decades, due to the increasing globalization of financial markets and communications as well as technological development. As Edwards \& Gill describe it, criminal organizations can nowadays "exploit opportunities for cross-border crime" thanks to the creation of such continental trading blocs as the North American Free Trade Association (NAFTA) and the European Union, developments in transport and communications technologies as well as the deregulation of international currency markets ${ }^{22}$. Thus, criminal activities can extend into two or more countries and violate their laws. As defined in the UN Convention Against Transnational Organized Crime, this type of criminal activity includes any criminal enterprise conducted in more than one state, or planned in one state and committed in another, or even perpetrated in one state but affecting neighbouring states ${ }^{23}$. The transnational character of organized crime means that criminal networks cooperate across borders and are able to overcome cultural, social and linguistic barriers in order to commit their crimes. Organized crime has become global and reached macro-economic levels when illegal goods obtained from one continent are trafficked across another and distributed in a third, for example, the flow of narcotics from Afghanistan and South America into Europe and the United States. Some examples of the most prominent transnational criminal groups are Italian Mafia, Chinese Triads, Japanese Yakuza, Colombian drug cartels, Russian and Nigerian organized crime groupings ${ }^{24}$.

Finally, although the phenomena of organized crime and terrorism have been traditionally considered separately, the process of globalization has brought real concern over the connections between them. Starting from the 1980s, when illegal drug production and trafficking were found to finance terrorists, organized crime and terrorism have more often been looked at simultaneously25. "When the two combine, terrorist organizations derive benefits from the drug trade with no loss of status, and drug traffickers who have forged an

22 A. Edwards, P. Gill, Crime as enterprise? The case of "transnational organized crime”, „Crime, Law and Social Change” 2002, No. 37, p. 203-223.

23 United Nations Office on Drugs and Crime, United Nations Convention...

24 J. Giraldo, H. Trinkunas, Transnational crime...

25 F. Bovenkerk, B.A. Chakra, Terrorism and organized crime, „Forum on Crime and Society" 2004, Vol. 4, No.1\&2, p. 3-15. 
alliance with terrorists become more formidable and gain in political clout"26. There can be found numerous examples of such cases in literature when terrorists benefited from criminal activities. Warlords in Africa, for instance, are known to have illicitly traded in diamonds, Iraqi insurgents - to have resold hijacked petroleum and trafficked in drugs, Al-Qaeda cells in Western Europe - to have been engaged in credit card fraud, and members of Hezbollah - in cigarette smuggling and coupon fraud in the United States ${ }^{27}$. Although there is no consensus among scholars whether organized crime and terrorism present a long-term strategic alliance, some authors note a similarity between both groups of criminals. According to Bovenkerk \& Chakra, both types use secret methods to carry out their activities, they also use the same or similar infrastructures and corruption networks, and they apply the same type of tactics by engaging in crossborder smuggling, money laundering, counterfeiting, kidnapping, extortion and various kinds of violence ${ }^{28}$. Thus, this nexus is seen as a real threat to both national and international security as "organized crime can use the power apparatus of political crime to create the social and economic context that makes its profitable activities feasible", whilst terrorist groups, on the other hand, "need funding to push their own agendas"29. Moreover, terrorists and organized crime groups may "converge in their motives" due to the radicalization of criminals by terrorists during periods when they are in close contact, for example, when sharing jail cells ${ }^{30}$.

\section{Organized crime in East Central Europe and Central Asia}

The three countries of East Central Europe - The Czech Republic, Hungary and Poland, can be of interest in terms of organized crime as recent political and economic developments in these countries have made them attractive to such criminal activities. According to Hignett, the roots of organized crime in this region date back to the 1970s, but after the revolutions of 1989 organized crime here

\footnotetext{
26 Ibidem, p. 4.

27 J. Giraldo, H. Trinkunas, Transnational crime...

28 F. Bovenkerk, B.A. Chakra, Terrorism and organized crime...

29 Ibidem, p. 6.

30 J. Giraldo, H. Trinkunas, Transnational crime...
} 
became "a significant problem with global implications" 31 . After the collapse of socialism, during the transition process to democracy and market economy, "chaotic economic conditions, weak law enforcement, a permissive legal framework, unprotected borders and porous financial systems all combined to provide an environment highly favourable to the development of organized crime in the region" 32 . For example, in the early 1990s in Hungary, due to the introduction of dual prices for different types of oil, the so-called 'oil mafia' took advantage of the situation and imported huge amounts of cheap oil which was then sold at much higher prices ${ }^{33}$.

It should be noted that the post-socialist economic reforms and the privatization process in each of the above-mentioned countries created favourable conditions for criminal groups to invest their illegal profits in the legal economy and, in this way, launder money or conduct further illegal activities. Moreover, criminal gangs of various nationalities from outside this region also grasped the opportunity to penetrate it in the early 1990s because the region, situated in the heart of Europe, presented for them perfect conditions for illicit transit of goods and people. Criminal groups from Arab countries, Africa, Asia, the Balkan region, Turkey, Western Europe and especially from the former Soviet Union are all active in East Central Europe today. For example, such criminal organizations as the Moscow-based Solntsevskaya mafia, the St. Petersburg Tambovskaya organization and many Chechen gangs are said to have been operating in the region since the mid-1990s ${ }^{34}$.

According to Adamoli et al., trafficking in drugs, prostitution, art objects, stolen cars and arms are types of organized crime typical of the region in question and in which local and foreign criminal groups have been traditionally engaged ${ }^{35}$. Moreover, due to recent development processes and transition to market economy, such crimes as illicit traffic in migrants, extortion, money laundering, and

${ }^{31} \mathrm{~K}$. Hignett, Organised crime in East Central Europe: the Czech Republic, Hungary and Poland, „Global Crime” 2004, No. 6(1), p. 70-83.

32 Ibidem, p. 72.

${ }^{33} \mathrm{~K}$. Hignett, Organised crime in East...

34 Ibidem.

35 S. Adamoli et al., Organised crime around the world, European Institute for Crime Prevention and Control affiliated with the United Nations, Publication Series No. 31, Helsinki 1998. 
tax evasion are on the rise here nowadays. Drug trafficking, for instance, poses the following two problems in this region: the creation of new transit routes across the region and the production of psychotropic and synthetic drugs and their international distribution. To give an example, the modern road and rail transportation systems in Hungary and the Danube-Rhine canal system create favourable conditions for heroin traffickers to transport their illegal goods to the West, and drugs from Latin America and Turkey continue to be smuggled through Hungary ${ }^{36}$.

Also Poland is used as a favourite route for trafficking heroin, hashish and other drugs to the West. Apart from that, Poland has also become a producing country. As Adamoli et al. observe, its "amphetamine industry constitutes the most sophisticated indigenous narcotics enterprise in Europe" where, thanks to the first-class laboratory equipment and highly qualified chemists employed by criminal groups, "the extremely high purity of the final product" is obtained ${ }^{37}$. Moreover, like in the case of many other criminal organizations in the world, Polish amphetamine gangs also invest in the legal economy. As for the Czech Republic, several professionally equipped laboratories producing drugs have been discovered in the country. Criminals also engage here in human trafficking, and in 2000 a network involved in illegal transportation of young girls for prostitution from the Czech Republic and Hungary into Austria was uncovered by the police 38 .

Another problematic region in terms of organized criminal activities is the region of Central Asia which includes several countries of the former Soviet Union - Kazakhstan, Kyrgyzstan, Tajikistan, Turkmenistan and Uzbekistan. These countries have suffered from many years of totalitarian rule and are still struggling to establish effective governance and law enforcement institutions. This fact as well as low economic development and high levels of unemployment make the region vulnerable to organized crime. After the collapse of the Soviet Union these states started to integrate with the global economy. However, they inherited "a tradition of corruption,

\footnotetext{
36 Ibidem.

37 S. Adamoli et al., Organised crime around...

38 K. Hignett, Organised crime in East...
} 
disregard for human rights and the rule of law, and an overall lack of public accountability of state institutions and officials"39.

Today criminal activities in the region of Central Asia include a wide range of crimes: trafficking in drugs, racketeering, control of prostitution, infiltration of the banking system and oil industry, car theft and trafficking in wildlife and in precious metals ${ }^{40}$. Trafficking in drugs, for instance has a significant influence on the security of the region. According to the assessment conducted by the United Nations Office on Drugs and Crime (UNODC) in 2006, drug trafficking in Central Asia undermines human security as the states in this region are now becoming consumer states, which results in increased levels of drug abuse, petty crime and drug-related diseases like HIV/AIDS ${ }^{41}$. It also increases the risk of political and economic instability through corruption and political dissatisfaction of citizens. Finally, it has an impact on national, regional and international security because armed rebel groups can increase the destabilization of the region. Of all the countries mentioned above, Tajikistan has suffered from drug business the most. The value of drugs smuggled through Tajikistan amounts to 30 per cent of the country's GDP ${ }^{42}$. One of the main reasons for that is the fact that Tajikistan shares a long border with Afghanistan and the drugs from Afghanistan for the Russian Federation flow through Tajikistan and then through Kyrgyzstan or Uzbekistan and finally Kazakhstan. Kazakhstan has also a serious drug problem. It is known to be the place of extensive cannabis cultivation as well as an important "trans-shipment point" for trafficking drugs from Central and South-West Asia to Russia and the West ${ }^{43}$. Other countries of the region have similar problems connected with drugs.

As far as other criminal activities are concerned, trafficking in firearms, smuggling of migrants, human trafficking, trafficking in organs, child prostitution, money-laundering, smuggling of tobacco

39 United Nations Office on Drugs and Crime, An assessment of transnational organized crime in Central Asia, New York 2006, p. 9, http://www.unodc.org/documents/organized-crime/Central_Asia_Crime_Assessment.pdf, (date of access: 29.11.2020).

40 Ibidem.

41 Ibidem.

42 Ibidem.

43 United Nations Office on Drugs and Crime, An assessment of transnational... 
and alcohol, and counterfeiting and cybercrime are crimes committed in Central Asia on a wide scale. Child prostitution in Kazakhstan, for example, represents a profitable business for criminal groups, and some children involved in it as child sex workers are as young as 8 years old, whilst in Kyrgyzstan smuggling of migrants has become a serious problem because illegal immigrants from Afghanistan, Bangladesh, India, Nepal, Pakistan, Somalia and Sri Lanka transit through this country to Russia, Western Europe, the United States of America or Canada ${ }^{44}$.

\section{Conclusion}

In conclusion, organized crime poses a serious threat to peace and human security at both national and international levels. It violates human rights and undermines economic and political development and stability of states. Organized crime is often characterized by a transnational nature and can manifest in various forms including trafficking in drugs, firearms and people, smuggling of migrants, and money-laundering. Criminals can influence public processes through corruption and can compromise legal economies through reinvestment of their illegal profits. In extreme cases, organized crime can even undermine the capacity of governments to protect their citizens. What is more, terrorists often rely on organized crime to fund and carry out their operations, which poses a serious threat to international security.

Organized crime has expanded aggressively in the last few decades thanks to the process of globalization and development of new technology and communications as a result of which new criminal markets and new forms of organization have developed. Organized crime can overcome cultural, linguistic, social and geographical barriers and it is becoming more difficult to fight. As Giraldo $\&$ Trinkunas observe, the global trends that promote greater political, economic and personal freedom, can also enable criminals "to transcend national jurisdictions" 45 . This is particularly true in the case of states that are in transition to democracy and free markets,

\footnotetext{
44 Ibidem.

45 J. Giraldo, H. Trinkunas, Transnational crime...
} 
especially in Central/Eastern Europe and Central Asia. Nevertheless, organized crime must be treated with an adequate response and new law enforcement strategies should be worked out by governments and international organizations.

\section{References}

Adamoli S. et al., Organised crime around the world, European Institute for Crime Prevention and Control affiliated with the United Nations, Publication Series No. 31, Helsinki 1998.

Bovenkerk, F., Chakra B. A., Terrorism and organized crime, „Forum on Crime and Society" 2004, Vol. 4, No.1\&2.

Edwards, A., Gill P., Crime as enterprise? The case of "transnational organized crime”, „Crime, Law and Social Change” 2002, No. 37.

Giraldo J., Trinkunas H., Transnational crime, [in:] Contemporary security studies, ed. Collins A., Oxford 2007.

Hignett K., Organised crime in East Central Europe: the Czech Republic, Hungary and Poland, „Global Crime” 2004, No. 6 (1).

Hough P., Understanding global security, London 2004.

Levi M., Perspectives on "organised crime”: an overview, „Howard Journal of Criminal Justice" 1998, No. 37(4).

Naylor R.T., Towards a general theory of profit-driven crimes, „British Journal of Criminology" 2003, No. 43.

Smith M. E., International security: politics, policy, prospect, Basingstoke 2010.

United Nations Office on Drugs and Crime, United Nations Convention against Transnational Organized Crime and the Protocols thereto, New York 2004, http://www.unodc.org/documents/treaties/UNTOC/Publications/TOC \%20Convention/TOCebook-e.pdf, (date of access: 29.11.2020).

United Nations Office on Drugs and Crime, An assessment of transnational organized crime in Central Asia, New York 2006, http://www.unodc.org/documents/organized-crime/Central_ Asia_Crime_Assessment.pdf, (date of access: 29.11.2020). 